
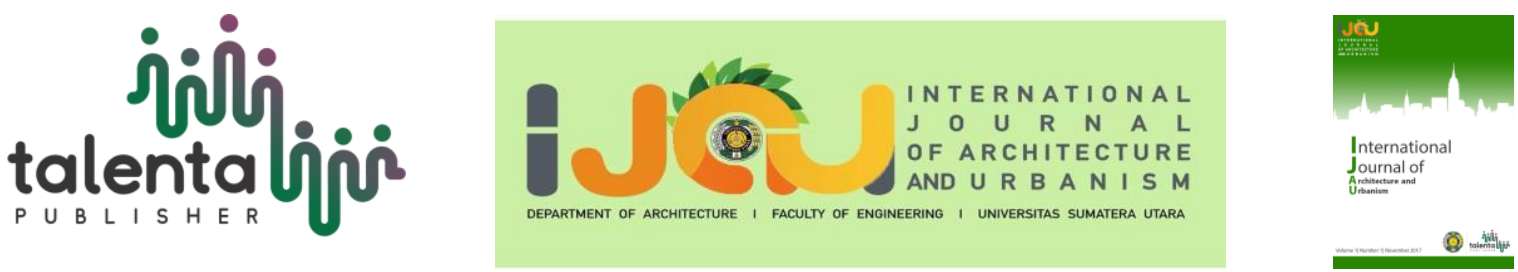

\title{
The Influence of Product and Façade Design towards Consumer Preferences
}

\author{
Imanuel N Mbake ${ }^{I^{*}}$, Marianus Bahantwelu ${ }^{I}$ \\ ${ }^{1}$ Architecture Department, Faculty of Science and Engineering, Universitas Nusa Cendana
}

\begin{abstract}
The façade is an architectural element that is to show the functional and meaning of the building. The façade design of a house is generally on the of the basic considerations for consumers to buy. In addition, the face design has always been a promotional information in the marketing mis that used by housing developers. This research was intended to admit the product and façade design effect towards consumer preferences in lower-middle housing. The object study was Pondok Indah Matani housing in Kupang, NTT. This research used experimental approach by manipulating research variables. The manipulated variables were product and façade design, while the influenced variables were consumer preferences. The determination of sample used purposive sampling method with a technical survey using a questionnaire. The result of study stated that the product and façade design had a significant effect on consumer preferences, through (1) the application of contrasting colors, (2) the firm boundaries in transition area in front of the house and (3) the complexity of the product dan façade design should be not too complicated so that it was easy to care post purchase.
\end{abstract}

Keyword: Product, Façade Design and Consumer Preferences

Received 22 July 2021 | Revised date month year | Accepted 22 August 2021

\section{Introduction}

House is a basic need or human physiological need beside cloth and food in Maslow's hierarchy [1]. The definition of the house has also changed along with human development in science and technology. The house is not limited to dwelling house but it becomes a place for selfactualization and investment for the owner [2]. Along with the population increasing, the demand for dwelling house and its availability has also increased. This condition has an impact on the emergence of housing. Housing defined as a collection of houses that built in a ready-tobuild area with facilities, infrastructure and public facilities to conform housing standards in livable residential areas [2]. At the first time, housing was organized by the government to occupy the community needs. However, in reality there were a new problem arises namely

\footnotetext{
*Corresponding author at: Nusa Cendana University, Architecture Department, Faculty of Science and Engineering, Adi Sucipto St., Kupang 85001, Indonesia

E-mail address: imanuelmbake@staf.undana.ac.id
} 
backlog. Backlog is defined as the number of houses that have not been or have not handled [3]. Therefore, the development of housing ultimately involves the private sector in the cooperation scheme. This cooperation scheme is generally providing the housing for middle to lower income people.

It has to accommodate two interests that is the interests of the government and the interests of the private sector. The government's interest is providing decent housing and reduce the backlog, which is increasing every year [3]-[4]. The interests of the private sector are certainly related to the return on investment [5]. It is depending on consumer purchasing decisions. In marketing context, housing units in a residential area are products that offered by developers to consumers [6]. Developers expected that its product should be noticed, demanded and sought by consumers to buy [7]. Products in an architectural perspective related to housing units that have several aspects, namely function, form and meaning [8]. But in this paper, we will focus on the form aspect of housing units. it becomes physical evidence that can be observed by consumers and in this context is the facade of the housing units.

Based on the description, the authors want to examine the product and the facade design effect on purchasing decisions at Pondok Indah Matani housing in Kupang. This housing is providing on housing units for lower-middle income people. It could be reached for 40 minutes from the city center and located in the border area between Kupang City and Kupang Regency. The object of study is type 45 of housing units. This is because the type has a large number of available units compared to other types. In addition, this type of housing unit had been changing in the facade design after 1 year of being purchased by consumers

\section{Literature Review}

\subsection{Product}

Products which offered by producers in the market, consist of consumer goods and industrial goods [9]. Housing units are consumer goods, cause it purchased to fulfill consumer needs and desires [10]. Products have two levels, that is consumer level and producer level [11]. Consumer level consist of

a) Core products are products that refer to the problem-solving benefits that search by consumers when they buy it.

b) Actual products are products that search by consumers with a basis consideration namely quality levels, features, designs, brand names and packaging.

c) Additional products are products that offered the additional benefits to consumers and it located between the core product and the actual product. Additional product that exists in the object of research which become a consideration point for consumer to buy that is daily clean water services. 
Furthermore, producer level consists of

a) The main products are products that actually needed and consumed by consumers.

b) Basic products are products that fulfill the most basic product functions.

c) Expected products are formal products that offered with various attributes and normal conditions which expected and agreed to be purchased.

d) Additional products are various product attributes that added by benefits and services so that it can provide additional satisfaction and could be distinguished from competing products.

e) Potential products are all forms of additions and changes which developed for its products in the future.

Products have elements that considered important and used as the basis for making purchasing decisions by consumers which are known as attributes [10]. Product attributes consist of

a) The brand, it refers to a name, term, sign, symbol, color, design that provides identity and differentiation between products. it must be distinctive, describe the benefits of the product and be easy to pronounce.

b) Product quality, which is the ability of the product to perform its functions as durability, reliability and accuracy. In the discussion of housing context, product quality is generally related to the neatness of the construction work of housing units.

c) Product features become product differentiators between producers. To be effective in the context of return on investment, producers must be the first to introduce new features.

d) Design is the heart of the product. Good design has a deep understanding of customers or users of its product.

e) Services. It's generally intangible but can be felt by consumers. Good service makes the producer's product able to compete with competing products in the market.

f) Guarantee is the responsibility of producers for the function of their products to consumers. Producers have to provide compensation to consumers if their products cannot function as expected or promised.

g) The price is amount of money that paid for an item or services which received by consumers. In housing market context, price have a psychological and economic impact on the product. If the consumer is satisfied with the product, the producer has been succeeded in increasing the consumption value of its product.

\subsection{Façade Design}

Gavin [12] defines facade as the front area of a building that characterizes the architectural style of the building. Even, Krier [12] details part of the elements that make up the facade that is

1) The door is a hole in the wall of a building that must exist in a building. The door becomes access to the inside and/or outside the building. Even, the shape and dimensions of the door can sometimes give an idea about the character of the building owner. 
2) The window is also a hole in the wall of the building that has the function of circulating air and light into and/or outside the building.

3) The wall is a room divider in the building against the outer space

\subsection{Consumer Preferences}

Consumer preference for a product has not become a demand because it has not been accompanied by purchasing power [13]. If approached from the Kotler [11] concept in the purchasing decision process, consumer preferences are in the stage of information seeking and alternative evaluation. In this stage, consumers look for the amount of information about the product before purchased. Next, the consumer will perform the product evaluation stage. At this stage, consumers assess whether the product meets their needs and whether the product attributes support the performance of the core product. Assael [14] defines consumer preferences as everything that is the choice of consumers. Consumer preferences are a good managerial input for the success of producer products in society. It's because consumer preferences are the basis of consumer purchasing decisions for products that offered by producers in the market.

Bainana et al [14] stated that there are several aspects that become basis for the evaluation of consumer preferences, that is the proximity of the location to the facilities around the housing, the presence of housing fences, security facilities, payments method, availability of clean water facilities, the form of road corridors in housing and house models. Anthony et al [15] state design factors that related to consumer preferences so it could affect product purchase decisions by consumers, that is the front view of the building, building plans, building specifications and product quality.

\section{Method}

The type of research approach that be used is experiment. it is done like investigative research with under controlled conditions, which is one or more variables are manipulated to test the hypothesis [16]. The manipulated variables are the product and the facade design, while the affected variables are consumer preferences. The method that used to compile data is a survey using a questionnaire tool. The scale method in the questionnaire is a Likert scale from a range of 1-5 which related to the level of cost of goods sold for products and facade designs of type 45 housing units. A score of 1 (one) for definitely to purchase, a score of 2 (two) for wanting to purchase, a score of 3 (three) for maybe to purchase, a score of 4 (four) for not wanting to purchase and a score of 5 (five) for definitely not to purchase. Furthermore, data from the Likert scale assessment be converted for each option, namely definitely to purchase (1), wanting to purchase (0.75), maybe to purchase (0.5), not wanting to purchase (0.25) and definitely not to purchase (0). The result of converted to see the percentage of consumer preferences for products and facade designs that have been manipulated. 
The population and sample in this study were people who were looking for information related to type 45 housing units at Pondok Indah Matani Housing in Kupang. Gay et al [16] stated that the minimum number of samples for this type of study with this approach is 15 samples. But in its development, there were 30 samples that obtained. The sample was determined by purposive sampling method.

\section{Result And Analysis}

The determination of the cost of products sold had been done after calculating the fixed costs and variable costs. The process of financial calculation has been done in previous study that is the effect of product and design on the selling price. Furthermore, the author provides 2 alternative facade designs to get a description of consumer preferences. The change from each alternative facade design is the application of finishing materials for the components of the cost namely masonry and plastering work, frame and window work and finishing. The below picture is an existing facade design of the 45-type house unit (Figure 1).

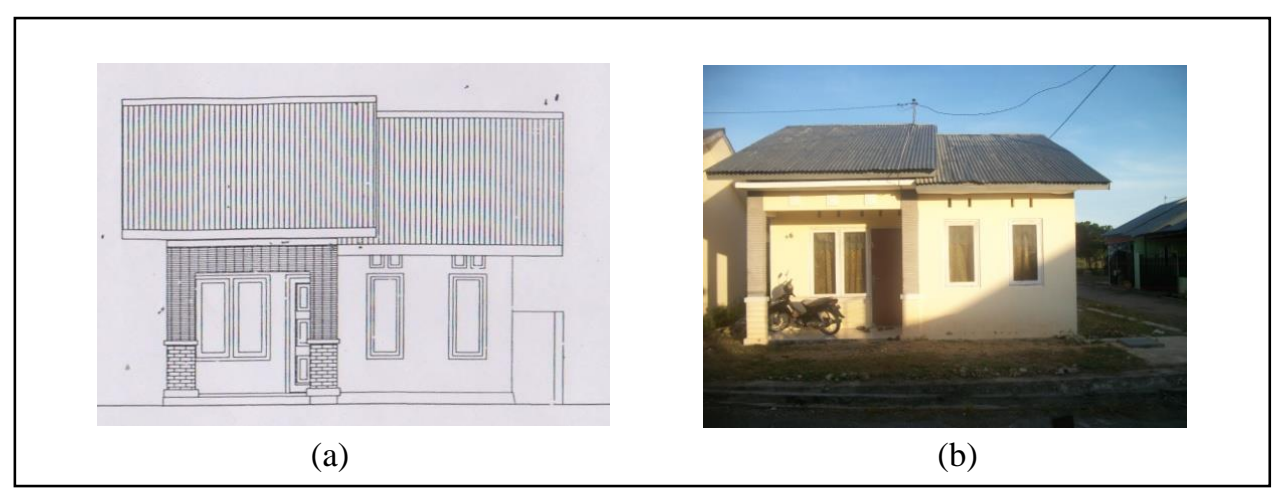

Figure 1. (a) an existing façade design (b) the house facade of type 45

Alternative façade design 1 applies the concept of modern architectural design. Adaptation to tropical climate conditions is achieved by wide window openings to maximize lighting and air circulation in the room. Another addition to maximize air circulation in the room is the addition of a bouvenlist above the window opening using glass material.

Consumer preferences in several studies state that product quality is the basis for consideration of product selection by consumers [7]-[14]-[15]-[17]. Based on those studies, the door and window frame materials use aluminum, while the door and window still use wood material.

Aesthetic aspects are a concern of this material selection beside the aspect of ease of construction and maintenance. The picture below shows us the comparison between alternative facade design 1 and the existing facade design (Figure 2). 


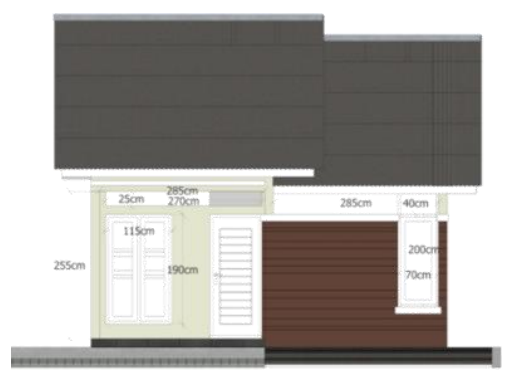

(a)

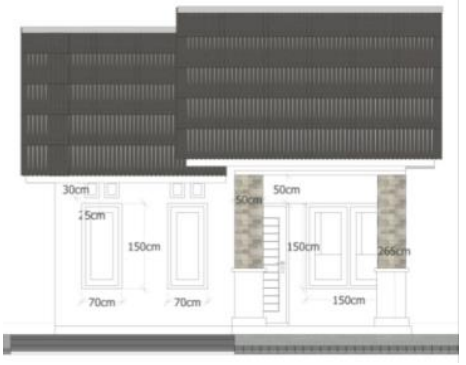

(b)

Figure 2. (a) the façade design alternative 1 (b) the existing model of façade design of house type 45

Alternative facade design 2 also applicated the concept of modern architectural design. In alternative facade design 2, there are no significant changes related to existing facade design. Finishing materials for door and window frames still use wood materials as the existing condition.

Design changes are only made on the dimensions of the terrace column and application paint for finishing materials than use natural stone materials as in the existing condition. The paint material is chosen in a striking color so that it can become a point of interest for facade the residential unit. The following is a comparison image of alternative facade design 2 and the existing design (Figure 3).

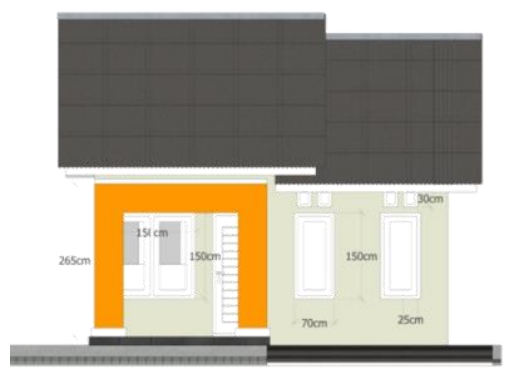

(a)

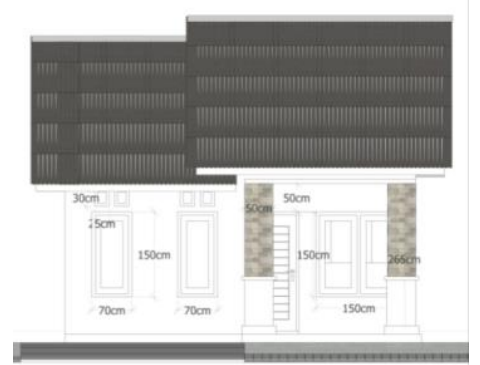

(b)

Figure 3. (a) the façade design alternative 2 (b) the existing model of façade design of house type 45

Each alternative facade design and existing designs have the same cost of sold. This condition gives an idea that for the same price, facade designs could be made in various developments. Of course, another consideration is the availability of the selected material during the construction and after-sales maintenance.

The next stage is to assess consumer preferences based on the facade design alternatives and the sold prices that have been calculated in previous studies. The background data of the respondents in the questionnaire are occupation, income and last education. These three aspects 
were chosen as aspects that also influence consumer preferences for the products and facade designs.

Based on questionnaire data for job categories, $46 \%$ of respondents are civil servants (PNS), $27 \%$ of respondents are self-employed and $27 \%$ are private employees. Furthermore, for the last education category, most of the respondents are Senior High School (SMA). The other respondents were under-graduate (S1) and graduate (S2) for educational backgrounds.

For the income category, most of the respondents have an income less than Rp. $1,500,000 /$ month by $17 \%, 30 \%$ of respondents have income between Rp. 1,500,000 to Rp. 2,000,000/month and Rp. 2,000,000 to Rp. 3,000,000/month. The remaining respondents of $23 \%$ have income above Rp. 3,000,000/month.

The next stage is to look at consumer preferences for the products and facade designs in alternative facade designs 1 and 2. The results of the questionnaire for alternative facade design 1 were as follows (Table 1)

Table 1. Experiment Result for Alternative Façade Design 1

\begin{tabular}{ccccccc}
\hline $\begin{array}{c}\text { Price } \\
(\text { Rp })\end{array}$ & $\begin{array}{c}\text { definitely } \\
\text { to purchase }\end{array}$ & $\begin{array}{c}\text { wanting to } \\
\text { purchase }\end{array}$ & $\begin{array}{c}\text { maybe to } \\
\text { purchase }\end{array}$ & $\begin{array}{c}\text { not wanting } \\
\text { to purchase }\end{array}$ & $\begin{array}{c}\text { definitely not } \\
\text { to purchase }\end{array}$ & Total \\
\hline 238.000 .000 & 11 & 12 & 5 & 2 & 0 & 30 \\
246.000 .000 & 4 & 11 & 11 & 4 & 0 & 30 \\
255.000 .000 & 2 & 7 & 12 & 5 & 4 & 30 \\
264.000 .000 & 1 & 5 & 4 & 14 & 6 & 30 \\
273.000 .000 & 1 & 0 & 5 & 6 & 18 & 30 \\
282.000 .000 & 1 & 0 & 0 & 5 & 24 & 30 \\
290.000 .000 & 1 & 0 & 0 & 0 & 29 & 30 \\
\hline
\end{tabular}

The results of the questionnaire for alternative facade design 2 were as follows (Table 2).

Table 2. Experiment Result for Alternative Façade Design 2

\begin{tabular}{ccccccc}
\hline $\begin{array}{c}\text { Price } \\
(\text { R } \boldsymbol{p})\end{array}$ & $\begin{array}{c}\text { definitely } \\
\text { to purchase }\end{array}$ & $\begin{array}{c}\text { wanting to } \\
\text { purchase }\end{array}$ & $\begin{array}{c}\text { maybe to } \\
\text { purchase }\end{array}$ & $\begin{array}{c}\text { not wanting } \\
\text { to purchase }\end{array}$ & $\begin{array}{c}\text { definitely not } \\
\text { to purchase }\end{array}$ & Total \\
\hline 238.000 .000 & 12 & 16 & 1 & 1 & 0 & 30 \\
246.000 .000 & 7 & 11 & 10 & 2 & 0 & 30 \\
255.000 .000 & 4 & 4 & 14 & 8 & 0 & 30 \\
264.000 .000 & 0 & 6 & 7 & 10 & 7 & 30 \\
273.000 .000 & 0 & 2 & 4 & 10 & 14 & 30 \\
282.000 .000 & 0 & 1 & 2 & 4 & 23 & 30 \\
290.000 .000 & 0 & 0 & 1 & 2 & 27 & 30 \\
\hline
\end{tabular}

Based on the results of the two questionnaires, it describes the theory of demand. it stated that the higher the price, the lower the level of demand. Vice versa, if the price goes down, then the level of demand will increase. 
The results of the questionnaire above were converted to see the level of consumer preference for the alternative facade designs. The results for alternative facade design 1 were as follows (Table 3).

Table 3. The Converted an Experiment Result for Alternative Façade Design 1

\begin{tabular}{ccccccc}
\hline $\begin{array}{c}\text { Price } \\
(R p)\end{array}$ & $\begin{array}{c}\text { definitely } \\
\text { to purchase }\end{array}$ & $\begin{array}{c}\text { wanting to } \\
\text { purchase }\end{array}$ & $\begin{array}{c}\text { maybe to } \\
\text { purchase }\end{array}$ & $\begin{array}{c}\text { not wanting } \\
\text { to purchase }\end{array}$ & $\begin{array}{c}\text { definitely not } \\
\text { to purchase }\end{array}$ & Total \\
\hline 238.000 .000 & 11 & 9 & 2.5 & 0.5 & 0 & 23 \\
246.000 .000 & 4 & 8.25 & 5.5 & 1 & 0 & 18.75 \\
255.000 .000 & 2 & 5.25 & 6 & 1.25 & 0 & 14.5 \\
264.000 .000 & 1 & 3.75 & 2 & 3.5 & 0 & 10.25 \\
273.000 .000 & 1 & 0 & 2.5 & 1.5 & 0 & 5 \\
282.000 .000 & 1 & 0 & 0 & 1.25 & 0 & 2.25 \\
290.000 .000 & 1 & 0 & 0 & 0 & 0 & 1 \\
\hline
\end{tabular}

The results for alternative facade design 2 were as follows (Table 4).

Table 4. The Converted an Experiment Result for Alternative Façade Design 2

\begin{tabular}{ccccccc}
\hline $\begin{array}{c}\text { Price } \\
(R p)\end{array}$ & $\begin{array}{c}\text { definitely } \\
\text { to purchase }\end{array}$ & $\begin{array}{c}\text { wanting to } \\
\text { purchase }\end{array}$ & $\begin{array}{c}\text { maybe to } \\
\text { purchase }\end{array}$ & $\begin{array}{c}\text { not wanting } \\
\text { to purchase }\end{array}$ & $\begin{array}{c}\text { definitely not } \\
\text { to purchase }\end{array}$ & Total \\
\hline 238.000 .000 & 12 & 12 & 0.5 & 0.25 & 0 & 24.75 \\
246.000 .000 & 7 & 8.25 & 5 & 0.5 & 0 & 20.75 \\
255.000 .000 & 4 & 3 & 7 & 2 & 0 & 16 \\
264.000 .000 & 0 & 4.5 & 3.5 & 2.5 & 0 & 10.5 \\
273.000 .000 & 0 & 1.5 & 2 & 2.5 & 0 & 6 \\
282.000 .000 & 0 & 0.75 & 1 & 1 & 0 & 2.75 \\
290.000 .000 & 0 & 0 & 0.5 & 0.5 & 0 & 1 \\
\hline
\end{tabular}

Based on the results of conversion, alternative facade design 2 was more chosen by respondents than alternative facade design 1 . This finding indirectly states that in addition to price and location, consumer perceptions are also influenced by products and facade designs which offered by housing developers [18]. Consumers will choose the design of the product that he finds attractive at the same price level [19].

In addition, consumer preferences will be high in housing units that have the characteristics of using natural colors and materials as well as matching colors but different tones (dark and light contrast) [20]. Kusuma [20] also stated that consumers are also considering the facade design that accommodates the transition space at the front. This is in line with the idea of alternative facade design 2 which uses a fairly contrasting color. In fact, the change in the dimensions of column on the terrace confirms the existence of a transitional space between the outside and the inside area of the building. It will be different in alternative facade design 1 which has a darker color. In addition, the absence of a dividing column in the terrace area confirms that there was no limit to the transition space in the front area of the house unit.

Consumer preferences be high, especially for residential designs that have a moderate level of complexity [20]. It was in line with alternative facade design 2 which has not significant changing from the existing design of the housing unit. It was different from the alternative 
facade design 1 which has a high complexity, especially used a wide glass bouvenlist in the front area of the building. Thus, consumers will consider aspects of care and cleanliness of the material when it will be occupied later. Wijaya et al [21] added that consumer preferences for lower-middle houses do not prioritize the location aspect but the quality product aspect, one of them was facade design of the housing unit.

The background factor according to Wijaya et al [21] also has a significant effect on consumer preferences for the facade design of the house unit. From the respondent's data processing, the majority of last education respondents were high school. This has an impact on respondents' preferences for the facade design. Therefore, it is not surprising that designs such as in alternative facade design 2 are widely chosen by developers to offer similar products to consumers around the object study location. Of course, with some small adjustments. so, it was not become plagiarism design between housing developers. The income aspect has no significant effect on consumer preferences for products and facade designs from the alternatives offered. The law of demand in an economic context become the main reference for consumer to the offered products.

\section{Conclusion}

Product and facade design have a significant effect on consumer preferences. Based on this study, the consumer preference also influenced by several aspects, namely

a) The application of contrasting colors is an attraction value for consumers.

b) The existence of a transitional space with clear boundaries is an attractive point for consumers. The transition space between the indoor and outdoor spaces could be modified into a living room.

c) The complexity of the product and the facade design is not complicated. it is to make it easier for consumers to maintenance post-purchase the housing units.

d) Consumer last education background is a factor that influences consumer preferences.

This study has not looked at the housing unit ownership factor as a consideration of consumer preferences. It is because consumers will sort out a lot of considerations for purchasing housing units that are occupied by themselves rather than housing units that purchased as investment assets. The limitation of housing unit class can also be extended to another study for uppermiddle class housing and high-end class housing. It is intended to see the phenomenon of consumer preferences for products in different classes with the same approach, means that we offering the alternatives facade design at the same sold price.

\section{REFERENCES}

[1] P. Haryono, "Arsitektur Humanistik menurut Teori Maslow" in Prosiding Seminar Nasional Sains dan Teknologi Ke-5 Tahun 2004, Fakultas Teknik Universitas Wahid Hasyim, Semarang: FTUnwahas,2004. pp. 26-31. 
[2] Badan Pembinaan Hukum Nasional, Undang-Undang Republik Indonesia Nomor 1 Tahun 2011 tentang Perumahan dan Kawasan Permukiman. Indonesia: bphn, 2011. [Online]. Available from bphn, https://www.bphn.go.id/data/documents/11uu001.pdf. [Accessed: July 06, 2021].

[3] Y. Rosa, "Rumusan Metode Perhitungan Backlog Rumah," Jurnal Permukiman, vol. 8, no. 2, pp. 58-68. 2013.

[4] Fahmi and R. Widyawati," Analisis Kebutuhan Pengembangan Perumahan dan Kawasan Permukiman Kabupaten Pesisir Barat tahun 2018 - 2037," Jurnal Profesi Insinyur, vol 1, no. 02 , pp. 40-53. 2020.

[5] I. Sururi and H. R. Agustapraja, "Studi Kelayakan Investasi Perumahan menggunakan Metode Benefit Cost Ratio," Jurnal Teknik, vol 18, no. 1, pp. 52-61. 2020.

[6] P. Kotler, Marketing Management, The Milenium Edition, Pretince Hall International. Inc, New Jersey, 2000.

[7] S. Widyasari, and E. T. Fifilia, "Analisis Pengaruh Produk, Harga, Promosi dan Lokasi terhadap Keputusan Pembelian Rumah (Studi pada Perumahan Graha Estetika Semarang)," Tema, vol 6, no. 2, pp. 159-169. 2009.

[8] B. Fauzy, Antariksa and P. Salura, "Memahami Relasi Konsep Fungsi, Bentuk dan Makna Arsitektur Rumah Tinggal Masyarakat Kota Pesisir Utara di Kawasan Jawa Timur (Kasus Studi Rumah Tinggal di Kampung Karangturi dan Kampung Sumber Girang, Lasem),” Dimensi, vol. 38, no. 2, pp. 79-88. 2011.

[9] P. Kotler, Prinsip-Prinsip Pemasaran Jilid I, PT Gelora Aksara Pratama, Jakarta, 2001.

[10] F. Tjiptono, Strategi Pemasaran. Andi Offset, Yogyakarta, 2000.

[11] P. Kotler, and K. L. Keller, Manajemen Pemasaran Jilid 2 Edisi 13, Erlangga, Jakarta, 2009.

[12] E. Prianto, "Strategi Desain Fasad Rumah Tinggal Hemat Energi," Riptek, vol 6, no. I, pp. 55-65. 2012.

[13] L. Arsyad, Ekonomi Manajerial, BPFE, Yogyakarta, 2008.

[14] W. Wardhani, U. Sumarwan, and L. N. Yuliati, "Pengaruh Persepsi dan Preferensi Konsumen terhadap Keputusan Pembelian Hunian Green Product," Jurnal Manajemen dan Organisasi, vol VI, no. 1, pp. 45-63. 2015.

[15] B. Anthony, N. Tresani, and R. P. Halim, "Preferensi Konsumen terhadap Faktor-Faktor Penentu Kepuasan Konsumen dalam Pengambilan Keputusan Pembelian Perumahan Bersubsidi di Karawang," Jurnal Muara Sains, Teknologi, Kedokteran dan Ilmu Kesehatan, vol. 1, no. 2, pp. 159-168. 2017. 
[16] M. Kuncoro, Metode Riset untuk Bisnis dan Ekonomi: Bagaimana Meneliti dan Menulis Tesis, Erlangga, Jakarta, 2003.

[17] K. Supriyono, L. B. Hasiholan, and M. M. Warso, "Pengaruh Produk, Harga dan Promosi terhadap Keputusan Konsumen dalam Membeli Rumah pada Perumahan Bukit Semarang Baru (BSB) City di Semarang," Skripsi Ekonomi Manajemen, Universitas Pandanaran, Semarang, 2014.

[18] B. Z. Zinas, and M. B. M. Jusan, "Housing Choice and Preference: Theory and Measurement,” Procedia-Social Behavioral Sciences, vol. 49, pp 282-292. 2012.

[19] P. H. Bloch, "Seeking the Ideal Form: Product Design and Consumer Response," Journal Marketing, vol. 59, no. 3, pp. 16-29. 1995.

[20] H. E. Kusuma, "Strategi Perencanaan Produk Perumahan: Pemetaan Preferensi terhadap Desain Rumah Tinggal,” Jurnal Manajemen Teknologi. vol. 9, no 1, pp. 95-106. 2010.

[21] A. S. C. Wijaya, T. Kwanda, and J. Rahardjo, "Faktor-Faktor yang Mempengaruhi Keputusan Pembelian Rumah dan Apartemen Kelas Menengah Bawah di Surabaya, Gresik dan Sidoarjo,” Jurnal Dimensi Utama Teknik Sipil, vol. 5, no. 1, pp. 1-8. 2018. 